\title{
Editor's message: the sunk cost fallacy of deep drilling
}

\author{
Jean-Christophe Maréchal
}

Keywords Crystalline rocks · Fractured rocks .

Groundwater exploration · India $\cdot$ Socio-economic aspects

\section{The observed facts}

At the beginning of 2008, I visited a watershed, located in Karkinatam village in the state of Karnataka, South India, where crops are intensively irrigated using groundwater. The water table had been depleted from a depth of 5 to $50 \mathrm{~m}$ in a large part of the area. Presently, $42 \%$ of a total of 158 water wells in the watershed are dry. Speaking with the farmers, I have been amazed to learn that they were drilling down to $500 \mathrm{~m}$ to tap water. This case is, of course, not isolated.

Large regions, for example in South America, Africa and South Asia, are constituted by crystalline rocks. The same regions face water scarcity under arid to semi-arid conditions. Therefore, fractured crystalline

Received: 7 April 2009 / Accepted: 1 August 2009

Published online: 2 October 2009

(C) Springer-Verlag 2009

Jean-Christophe Maréchal is an Associate Editor of Hydrogeology Journal.

\section{J.-C. Maréchal (汭)}

Indo-French Cell for Water Sciences; IISc-IRD (Institut de

recherche pour le développement) Joint laboratory,

Indian Institute of Science,

560012, Bangalore, India

e-mail: jean-christophe.marechal@ird.fr

e-mail: jc.marechal@brgm.fr

\section{J.-C. Maréchal}

Laboratoire des Mécanismes et Transferts en Géologie (Université Paul Sabatier, Centre national de la recherche scientifique, Institut de recherche pour le développement), Université de Toulouse, 14 Av Edouard Belin, 31400, Toulouse, France aquifers constitute groundwater reserves that are exploited in many parts of the world. In India, groundwater pumped from hard rocks represents the main resource for irrigation and has been sustaining the Green Revolution (Swaminathan 2007) for several decades. The mining of groundwater resources leads to lowering of the water table. As a reaction, the farmers are ready to pay more for deeper boreholes which, most of the time, are found to be dry. This trend is not restricted to rural areas, as private well development in the cities faces the same trend. A detailed study of groundwater extraction in the world shows that the examples of the deepening of wells up to hundreds of meters for water exploration in hard rocks are not limited to India but are also found in large numbers in other regions of the world (USA, Africa, etc).

\section{The scientific knowledge}

The concept that groundwater flows in crystalline rocks predominantly occur in a shallow higher-permeability zone ("active" zone) that overlies a deeper lowerpermeability zone hosting little flow ("inactive" zone), is now accepted. This has been documented in mountainous regions (Mayo et al. 2003) and in flat bedrock areas (Davis and Turk 1964; Dewandel et al. 2006; Maréchal et al. 2004). Some flows occur in the inactive zone and can be significant on a geologic timescale but can hardly sustain intensive pumping at a daily timescale.

The pioneering work of Davis and Turk (1964) on crystalline rocks of eastern United States was one of the first to describe a decrease of hard-rock permeability with depth. In Scotland (UK), a trend in decreasing mean permeability with depth in bedrock has also been observed on the basis of data from the Altnabreac granite (Holmes 1981). In the Victoria Province of Zimbabwe, below a 15-20 m thick regolith, the fractures of the top $20 \mathrm{~m}$-thick zone of fractured rock are found to be crucial 
for the provision of an adequate yield (Houston and Lewis 1988). This has been confirmed by Chilton and Foster (1995). Higher permeability at shallower depths is generally attributed to a greater degree of weathering and/or smaller overburden loads allowing more fractures to remain open. The thickness of the active layer is dependent on local geological settings. In the gneiss of South India, the interpretation of multiple pumping tests identifies an active part of the aquifer of about $25-35 \mathrm{~m}$ thickness (personal data), while in the crystalline bedrock of New Hampshire (USA), the well yield increases to approximately $130 \mathrm{~m}$ depth (Drew et al. 2001). In South Korea, the specific capacity of the wells is at a maximum above 80-m depth (Cho et al. 2003), and in a granitic area of South India, it is observed that the cumulative airlift flow rate increases drastically in the weatheredfractured layer between 20 and $30 \mathrm{~m}$ deep; below $30 \mathrm{~m}$, the flow rate is constant and does not increase with depth. In practice, drilling deeper than the bottom of the weathered-fractured layer does not increase the probability of improving the well yield (Maréchal et al. 2004).

The initial conceptual model of hard-rock hydrogeology, with the most productive zones located at the base of the regolith and the top of the fractured-weathered bedrock (Foster 1984), has been confirmed in various countries (Acworth 1987; Barker et al. 1992; Dewandel et al. 2006; Wright 1992). The data confirm that the weathered-fractured layer is the most productive part of the hard-rock aquifer compared to the deeper fresh bedrock (Taylor and Howard 2000).

As a general rule, fractures near the bedrock surface are most numerous and have the largest openings, so that the yield of most wells is not increased by drilling to depths greater than the bottom of this active zone. Exceptions to this occur where water-bearing faults or fractured zones, due to tectonic activity, are present at depths as great as 200-300 m. Nevertheless, statistically, it is clear that beyond the active zone, the probability of increasing the yield of a given well in hard rocks is very low.

\section{Stop the sunk cost fallacy}

One can observe a gap between hydrogeological practice and science. The most probable reason to explain this gap is called, in psychological sciences, the escalation of commitment. This phenomenon is where people justify increased investment in a decision, based on the cumulative prior investment, despite new evidence suggesting that the decision was probably wrong (Staw 1976). In economics and business management, it is well known as the sunk cost fallacy: increasing the resources available to an unsuccessful venture in the hope of recovering past losses. More generally, the sunk cost effect is manifested in a greater tendency to continue an endeavor once an investment in money, effort, or time has been made (Arkes and Blumer 1985). In water exploration, the escalation of commitment consists of drilling a borehole deeper in the hope of recovering the money wasted to drill the first dry meters. Once started, it is difficult to decide to stop drilling if the well is dry because the driller thinks that expected water-bearing structure could be a few meters away. This is similar to the compulsive gambler who needs, after losing, to gamble again to recover his losses. Of course, it can sometimes happen that a dry well becomes productive after deepening but, as suggested by the limited thickness of the active zone, it becomes a matter of luck.

This escalation of commitment for drilling deeper and deeper may be encouraged by drilling companies as the potential money gains are increased. In India, the cost of dry deep wells has become unaffordable for most of the farmers. The rate of farmer suicides has reached high levels as they cannot reimburse loans undertaken for increased expenses, among which are well drilling costs (Sainath 2004). As water engineers and water experts, our duty is to contribute towards ending this unreasonable trend of well-deepening in hard rocks. This could be done by making better drilling plans, and includes the a priori definition of a maximum drilling depth according to local hydrogeological knowledge and statistical information on the local relationship between yield and depth (Wright 1992). After that depth has been reached, instead of drilling deeper, the borehole should be closed.

\section{References}

Acworth RI (1987) The development of crystalline basement aquifers in a tropical environment. Q J Eng Geol 20(4):265-272

Arkes HR, Blumer C (1985) The psychology of sunk cost. Org Beh Human Decision Proc 35(1):124-140

Barker RD, White CC, Houston JFT (1992) Borehole siting in an African accelerated drought relief project. In: Wright EP, Burgess EG (ed) Hydrogeology of crystalline basement aquifers in Africa. Geol Soc Lond Spec Pub 66:183-201

Chilton PJ, Foster SSD (1995) Hydrogeological characteristics and water-supply potential of basement aquifers in tropical Africa. Hydrogeol J 3(1):3-49

Cho M, Choi Y, Ha K, Kee W, Lachassagne P, Wyns R (2003) Relationship between the permeability of hard rock aquifers and their weathering, from geological and hydrogeological observations in South Korea. In: Krasny J, Sharp J (eds) Groundwater in fractured rocks. International Association of Hydrogeologists Selected Papers, Prague, 15-19 September 2003

Davis SN, Turk LJ (1964) Optimum depth of wells in crystalline rocks. Ground Water 2(2):6-11

Dewandel B, Lachassagne P, Wyns R, Maréchal JC, Krishnamurthy NS (2006) A generalized 3-D geological and hydrogeological conceptual model of granite aquifers controlled by single or multiphase weathering. J Hydrol 330(1-2):260-284

Drew LJ, Schuenemeyer JH, Armstrong TR, Sutphin DM (2001) Initial yield to depth relation for water wells drilled into crystalline bedrock: Pinardville Quadrangle, New Hampshire. Ground Water 39(5):676-684

Foster SSD (1984) African groundwater development: the challenges for hydrological science. IAHS Pub 144:3-12

Holmes DC (1981) Hydraulic testing of deep boreholes at Altnabreac: development of the testing system and initial results, British Geological Survey, Keyworth, UK 
Houston JFT, Lewis RT (1988) The victoria province drought relief project. II. Borehole yield relationships. Ground Water 26(4):418-426

Maréchal JC, Dewandel B, Subrahmanyam K (2004) Use of hydraulic tests at different scales to characterize fracture network properties in the weathered-fractured layer of a hard rock aquifer. Water Resour Res 40, W11508

Mayo AL, Morris TH, Peltier S, Petersen EC, Payne K, Holman LS, Tingey D, Fogel T, Black BJ, Gibbs TD (2003) Active and inactive groundwater flow systems: evidence from a stratified, mountainous terrain. GSA Bull 115(12):1456-1472

Sainath P (2004) When farmers die. The Hindu, June 2004. http:/ www.indiatogether.org/2004/jun/psa-farmdie.htm
Staw BM (1976) Knee-deep in the big muddy: a study of escalating commitment to a chosen course of action. Org Beh Human Perf 16(1):27-44

Swaminathan MS (2007) Can science and technology feed the world in 2025? Field Crops Res 104(1-3):3-9

Taylor R, Howard K (2000) A tectono-geomorphic model of the hydrogeology of deeply weathered crystalline rock: evidence from Uganda. Hydrogeol J 8(3):279-294

Wright EP (1992) The hydrogeology of crystalline basement aquifers in Africa. In: Wright EP, Burgess EG (ed) Hydrogeology of crystalline basement aquifers in Africa. Geol Soc Lond Spec Pub 66:1-27 